\title{
Indian View of Peace and Development Leading to Global Harmony and Unity
}

\author{
Mousumi Das \\ Designation -Assistant Professor Of The Department Of Philosophy. S.S Jalan Girls' College.
}

The Indians think in a different way. Their philosophy, value systems, culture are different from the western counterparts. The political history of the Occident bore evidences that the centre of their life was the achievement of power. Thus, to the west, State attained a pivotal role and the system of power revolved round the State. In India, the centre of life was the society and not the state. In pre British India we can find a ruling power like a king or emperor but he was only a ruler .The development and the welfare of the common people were vested only on the society. Arthasastra and Manusamhita bore evidences of some specific duties and general duties to be performed by the people for the all round development of the society. S.K.Mitra in his book The Ethics of the Hindus stated that Manu distinguished between relative duties (varnaasśrama dharmas), i.e., duties relative to one's station of life, and common duties (sādhāranadharmas), i.e., duties of universal scope and validity. The relative duties are the specific duties relating to one's station in life, i.e., one's station as determined by one's varna or caste and one's aśrama or particular stages of life. The universal duties are the duties irrespective of one's age, caste, or creed, i.e., duties obligatory on man as man and not as a member of a particular community or social class. Manu enumerated that there are ten sādhāranadharmas or common duties of men. They are steadfastness(Dhṛti),Forgiveness(Kșamā),Application(Dama),Avoidance of theft(Cauryābhāva),Cleanliness(Śauca),Repression of sensibilities and sensuous appetites(Indriyanigraha),Wisdom(Dhĩ),Learning(Vidyā),Veracity(Satya),Restraint of Anger(Akrodha). ${ }^{1}$ Every individual residing in society needs to follow them. These duties were ascribed to them to maintain the peace, prosperity, and harmonious development of the society. We could find mentioning of such ethical virtues in the Vedas, Upanishads, Puranas, Ramayana, Mahabharata, and Gita and in the different schools of Indian philosophy. In this chapter, we would discuss how these ethical virtues and principles lead to the development of peace and harmony of Indian society and their influences on global harmony as a whole.

The earliest manifestation of Indian spirituality is found in the Vedas. The Modern Hinduism defines itself as the religion of the Vedas; they regarded Vedas as the foundation, and essence of the Hindu way of life. The Vedas and Upanishads speak of the ways of attaining spirituality by establishing a harmony with all beings. In the Upanishads repeated emphasis has been given on the fact that peace and harmony can be attained not by refraining oneself from activities but by establishing a living connection with all objects.

Vedic literature as mentioned in the book Indian Religions is divided into two main categories, the samihitās or "collections", most of which are in verse, and the commentaries or brāmaṇas, most of which are in prose. The three main samhitās are the Rg Veda, and Yajur Veda and the Sāma Veda; and Atharva Veda, a later text, is sometimes listed as fourth. The brāmanas consists primarily of explanations of the elements of the sacrifice; appended to them as the most esoteric ăranyakas (forest books) and upanisads. ${ }^{2}$ The word Upanisads is made of word elements upa, ni, and sad, which are generally explained as meaning as "sitting down near". The picture thus evokes is a group of students at the feet of the instructor in a secret "teaching session." In the Upanisads themselves, the term denotes 'secret knowledge' or 'secret teachings'.

"Śamkara derives the word upanisad as a substantive form the root sad, 'to loosen', 'to reach' or 'to destroy' with upa and ni as prefixes and kvip as termination. If this derivation is accepted, upanisads means brahma-knowledge by which ignorance is loosened or destroyed. The treatise that deals with brahma-knowledge is called the upanisads and so pass for the Vedanta. The different derivations together make the upanisads give us both spiritual vision and philosophical argument." ${ }^{3}$

The Upanisads teaches us that the world of multiplicity is in fact reducible to one single primary reality that reveals itself to our senses in different forms. This reality is hidden from senses but is discernible to reason. The question that is repeatedly asked in the upanisads is that what is the reality that remains identical and persists through all changes? The answer is given in the upanisads themselves as that supreme reality is

\footnotetext{
${ }^{1}$ Maitra Susil Kumar,The Ethics Of The Hindus,Calcutta,University of Calcutta, first published in 1963,pp.7-8.

${ }^{2}$ Peter Heehs (Edited).Indian Religion, the Spiritual Traditions of South, Delhi: Permanent Black, First published in 2002, pp.40-41.

${ }^{3}$ Radhakrishnan.S (Edited).The Principal Upanisads,New York: George Allen \& Unwin Ltd, First published in 1953, p.20
} 
Brahman. Brahman is derived from the root brh, which means to burst forth. Samkara derives the word Brahman from the root 'brhati which means to exceed and atișayana meaning eternity and purity. In the Rg Veda, we find Brahman is used in the sense of sacred knowledge of utterance, a hymn, or incarnation, the concrete expression of spiritual wisdom. It is the mystical power that contains within itself the essence of the thing denoted. The Brāmanas denotes Brahman as omnipotent and it is said that he who knows the Brahman becomes the primal principle and the guiding spirit of the universe. Brahman thus is the most ancient and brightest of all things. ${ }^{4}$ It is that from which all beings are born, that in which all beings enter at their death.

Thus, we find that the word Brahman suggests a fundamental kinship between the aspiring spirit of man and the spirit of the universe that it seeks to attain. We wish to know the universe suggests that we know the universe to some extent. If we do not know the Brahman then it would be impossible for us to say that it exists. We know the Real because the real knows itself in us. The feeling in every human being that he is in bondage vouch the existence of some reality to which we are all striving to reach. All our experiences, our limited existence tells that there is a greater reality in us though we do not know what it is. We know that it exists but do not know it fully. Our spiritual progress is nothing but a path from half-knowledge to a clear illumination of the reality. From every movement that stirs in us and every utterance that issues from us, we can perceive the power that moves us. That power is Brahman. The upanisads describes the nature of Brahman as sat or being, it or consciousness and ananda or bliss. Thus, Brahman is eternal bliss and those who have attained it attain eternal bliss.

In the early prose of the upanisads it is said that atman is the individual consciousness and the Brahman is the super personal ground of the cosmos. Soon the distinction diminishes and the two are identified. Brahman is not merely transcendent numinous other, but it is also the universal spirit, which is the basis of human personality and its ever-renewing vitalizing power. Brahman the first principle of the universe is known through ătman, the inner self of man. We find in Satapatha Brāhmaṇa and in the Chāndogya Upanisads it is said: 'Verily the whole world is Brahman', and 'This soul of mine within the heart, this is Brahman'.

Thus from the nature of Brahman or Supreme Reality as depicted in different upanisads it is clear that the upanisads insists the importance of ethical life. It repudiates the self -sufficiency of the ego and put emphasis on the practice of the moral virtues. The upanisads views man as responsible for his own acts. Man performs evil acts when he is imperfect, his finite self-when alienated from the Real infinite. When man acts using his freedom for his own exaltation, evil occurs. Man himself is Divine. However, the element of nonbeing present in man exposes him to evil. However, as a spiritual being man can break asunder the revolving circle of nature and come in Unity with the Absolute. However, how can man break the narrow walls of the finite? The answer is given in the upanisads themselves. In the famous sloka of the Isa Upanisads we find a answer of the question.It is said in the first sloka of Isaupanisad-

Ishāvāsyam idam sarvam yat kinch jagatyām jagat

Yěna tyaktěna bhunjithā mā gradha kasyasvit dhanam

The meaning of the verse goes that when we know the multiplicity of things as the final truth, we try to augment ourselves by the external possessions of them; but when we know the Infinite Soul as the final truth, then through our union with it we realise the joy of our soul. Therefore, it has been said of those who have attained their fulfilment they enter into all things. All things thus that move in the moving world is enveloped by God. Therefore, we must find our enjoyment in renunciation; we must not covet what belongs to others. Thus, it teaches us the most important human value. By 'tyaktěna bhunjithā' the Isa upanisad teaches us to enjoy through renunciation of self will. We should enjoy all things by renunciation the idea of personal proprietary relationship to them. Thus when we can realize that the world is not ours that we enjoy it, we can then only get rid of the cravings of acquisition it. When we can know that the Real indwells all and is manifested in all, we can attain the true knowledge. When the individual is in ignorance, he is not conscious of the unity and identity that underlies these multiplicities of creations. He at the stage cannot enter into harmony and oneness with the universe and thus fails to enjoy the world in true sense. He thinks that his property is his own and craves for more. Nevertheless, when he realizes his true existence that is centered in the Devine, he becomes free from the selfish desires and possesses. He then begins to enjoy the world in a spirit of non-attachment. This may be illustrated by an example. In the absence of adequate light, we mistake rope as a snake. However, when in the proper light, we correct our mistake, all our confusion goes away, and we have the true knowledge of the rope. Similarly, when human beings are shrouded in ignorance he mistakes the world as his own and considers him as alienated from God. However, with the true knowledge all his false knowledge disappears and he feels his unity with all beings. ${ }^{6}$ Thus, we must work in a purified heart by working with the notion that these are all for the sake of Lord and dedicate them to him. Works done in this spirit do not bind the soul.

\footnotetext{
${ }^{4}$ Ibid, Radhakrishnan.S (Edited).The Principal Upanisads,pp.52-53

${ }^{5}$ Ibid, Radhakrishnan.S (Edited).The Principal Upanisads,p. 77

${ }^{6}$ Swami Lokesarananda, Isapanisad, Upanisad,Kolkata:Ananda publishers, first published in 1999,p.4
} 
The same tune can be heard in the verses of Bagvad Gita.In the Karmayoga of Gita, Lord Krishna teaches the yoga of action. He declares that those who follow the path of knowledge need not withdraw from the world. What is needed Krishna, explains, is the renunciation not in action but of the desires for the fruits of the action. In Vedas, many sacrifices are prescribed for the individual. Nevertheless, these sacrifices should not be done for self-interest. Thus, Krishna in Gita insists us to sacrifice but without any regard to fruit. The true sacrifice is the offering of everything done to the Supreme.

In Buddhism, too we can find the same philosophy. Buddha teaches us the Noble Eightfold Path as the way leading to the cessation of suffering and the achievement of self-awakening. It is used to develop insight into the true nature of phenomena (or reality) and to eradicate greed, hatred, and delusion. The Noble Eightfold Path is the fourth of the Buddha's four noble truths. The eight fold is also known as the Middle path.

Among the Eight-fold path prescribed by Buddha Right Outlook means to know suffering, the origin of suffering, the cessation of suffering and the path that leads to the cessation of suffering. Right Resolve is to resolve to renounce the world and to do no hurt or harm to others. Right Speech is to abstain oneself from lies, slander and tattle. Right Act is to abstain from taking life and from any kind of theft or lechery. Right Livelihood is that by which one should exclude himself from all the wrong modes of living. Right endeavor is individual's struggle in heart to stop all the bad qualities that have arisen and to foster good qualities in their place. Right Mindfulness is realizing what the body is, what feelings are, and what mental states are. Right Mindfulness is thus freedom from the wants and discontent of any of these things. Right Rapture is when the individual is divested from all lusts and wrong dispositions. He then dwells in ecstasy with all his zest and satisfaction, a state bred of aloofness but not divorced from observation and reflection. He dwells in inward serenity, in pure concentration. ${ }^{7}$

Thus following the eight-fold path one can attain peace and serenity. Buddhism also speaks of four sublime moods by practicing which individual can reach universal fraternity with all beings. These four sublime moods are known as Brahmavihara, which form a sequence of Buddhist meditations. The Bramaviharas are recommended in the Pali Brahmavihara Sutta and the Sanskrit Brahmavihara Sutta. Among the four sublime moods, the first is Metta, which means loving kindness towards all in the hope that all people will be well. The second is Karuna meaning compassion. One should extend compassion to others in the hope that everyone's suffering will diminish. The third is Mudita or the altruistic joy in the accomplishments of a person, oneself or others. The last one is Upekkha or equinimity.It is learning to accept loss and gain, praise and blame, success and failure with detachment equally for oneself and for others. While Metta and Karuna are both hopes for the future, leading where possibilities to action aimed at realizing those hopes, Mudita and Upekkha are attitudes to what has already happened but also having consequence for future actions. By practicing these four sublime moods, an individual can enter the abode of God. Then one dwells in supreme bliss. ${ }^{8}$

The Jainas also maintains a series of vows, which have the aim to live in fraternity with all living beings. The most important of the vows is to desist from the knowing or intentional destruction of all great lives. This means we must refrain from killing to any animals or human. He must also refrain others from killing or harming. Such activities of killing must be refrained by all individuals in body, mind, and speech. The most important teachings of the Jainism are the teachings of Ahimsa with all beings.

The Sanskrit word 'Ahimsa' is derived from the Sanskrit root 'hims' meaning to strike. The literal meaning of ahimsa is not injuring anything or harmlessness ${ }^{9}$.Patanjali describes it as the removal of desire to kill. In a presence of a man perfected in ahimsa (non-violence) enmity in any creature does not arise. Sir Monier Williams in Sanskrit English Dictionary states the meaning of Hinsa as injury or harm (to life, property) hurt mischief, wrong. This Hinsa as mentioned is of three types-i) as hearing malice.ii) verbal or abusive language.iii) personal acts of violence. Ahimsa means kindness to all living beings including animals. Avoidance of verbal and physical violence is also a part of this principle although ahimsa recognises selfdefence when necessary as assign of strong spirit. The Hindus specially agrees to the point that violence in self defence especially in war can be justified. In Jaina school the understanding and implementation of ahimsa is more radical, scrupuluos and comprehensive than any other religion .Non-violence is seen here as the most essential religious duty of everyone (ahimsa parama dharmah).Ahimsa to the jainas is abstinence from everything that has life. It is not mere negative abstention, but also positive kindness to all creations. The traditional Buddhist understanding of ahimsa is not as rigid as the jainas but like the Jaina the Buddhist has always condemned the killing of all beings. The Buddhist accepts ahimsa as one the five silas (pancasila). The

\footnotetext{
Radhakrishnan.S and Moore.A.Charles (Edited).A Source Book of Indian Philosophy,New Jersey: Princeton University Press, First published in 1957, p.227-228.

${ }^{8}$ Singh .N.K and Mishra.A.P. (Edited), Encyclopaedia of Oriental Philosophy and Religion, Vol-8, New Delhi: Global vision Publishing House, First published in 2007, p.126-127.
}

${ }^{9}$ A HINDU PRIMER BY Shukavak .N.Dasa. 
five silas are i) Not to kill any living beings whatsoever (non-violence) ii) not to accept anything that has not being gifted.iii) Not to lie-in iv) To abstain from all kinds of himsa.v) sexual abstinence. ${ }^{10}$

Ahimsa is of three types-i) non- violence in thought. It means not to think ill of others and not to wish evil to any man. A man should treat others like his own self. (Ātmavat Sarvabhũteșu).ii) non- violence in wordsIt means to refrain from speaking such words, which cause pain to others. One should speak truth in gentle language. Non -violence in words require control of tongue preceded by control of thought. Control of tongue means not to speak unnecessarily and without any purpose.iii) Non-violence in deed-it means not to inflict physical injury to others or kill others. ${ }^{11}$

Ahimsa as depicted in the different Indian schools and texts has several characteristics. Firstly, it does not mean any kind of submission to the evil.But, at the same time it implies not to hate the evil -doer. If an evil -doer does any harm to a person in the path of ahimsa his path would be to save himself from the harm inflicted by evil- doer. Moreover, at the same time he should learn a lesson of not harming an evildoer. If a person is led astray from the path of celibacy, he should have enough courage to refuse to yield to the will of the temper and if no other alternative is left, he may sacrifice his life for the sake of chastity and morality. If a person is forced to speak a lie, he should offer resistance and should always stick to the truth even though others misunderstand him. A man is a man not because of any devil nature but because of the good nature in him. The value of truth always has its own reward in the test of time.Thus; in the end of life, the good habits only bear fruit. Even if a man, observing a detachment from worldly possessions should not hesitate to disobey the commands to the contrary, for his disobedience would help him to attain the goal. Secondly, Ahimsa is connected with justice and discipline. Justice means to give reward or punishment to the person according to his deed. Thus, a wrong doer if required should be subjected to fine to the proper authority for if he is led to go scot-free it would only mean to support himsa.

Ahimsa has two aspects-positive and negative. Negative ahimsa consists in not to harm others, not to speak harsh words, not to humiliate, not to exploit others, to desist from cruelty, anger to all animals and men ,not to oppress the weak or hurt their self respect.

The positive aspect of Ahimsa is the cultivation of love and goodwill towards all. Love implies compassion (Karuṇā), forgiveness (Kșamā) and disinterested service (Sevā).A Ahimsaka would unconditionally love all and help them who require his help. Ahimsaka believes in the principle that an evil cannot be overcome by evil. Tit -for- tat is not the accepted way of thought in the Indian system. Only the force of love can bring peace and harmony to the society. It requires of a non-violent man to develop inner strength to restrain the feeling of retaliation and hatred and thus to have the power of forgiveness. Positive Ahimsa also requires fearlessness and inner strength. Fearlessness does not mean misusing the power by torturing the helpless and weak .It means to forgive the person who have done wrong to the ahimsaka by mistake or may be in ignorance. In doing so, a time will come when the wrong doer will repent for his mistakes and will change his mind- set forever. Positive ahimsa also requires a non- violent man to be charitable. Charity is an aspect of goodwill and is attached to the kind side of human nature.Charita implies the disposition to share things with those who need them. It is to give away the excess of one, which is the root cause of all disputes. Charity is thus an unselfish act.

Ahimsa is also connected with justice. It shuns any kind of favouritism done to anyone and thus taking an unbiased attitude to all. Ahimsa requires wisdom, discretion, and intellect. An ahimsaka understands other's experiences and make it own. He realises others circumstances and their viewpoints, purposes and motives. He is empathetic to others and feels in the same way as others. Nevertheless, at the same time he is firm enough not to indulge any unrighteousness and untruth. Practicing non-violence requires a mastery over all desires and passions and working in a disinterested fashion. It requires a true knowledge of the ephemeral world and the temporeority of the relationships with ones kith and kin. Thus, he then develops a disinterested attitude towards the world and seeks to do for others what he does for himself. ${ }^{12}$

Mahābhārata and Ramayana bore testimony that Ahimsa was a major virtue. Ahimsa in the positive form has been used in various forms in Mahābhārata. Forgiveness has been highly praised in Mahābhārata. Forgiveness means not to return evil for evil but to keep patience and perseverance and win the opponent by means of fortitude. Dr Koshelya Walli in her book Ahimsa in Indian Thought has cited an instance from the epic to explain forgiveness. "In Mahābhārata, Draupadĩ the queen of Yudhișthira suggested him to give up forgiveness towards Kurus and show his might but the abode of forgiveness, Yudhișthira replied that the anger in this world was the root of all destructions. A man, dominated by anger, is unable to discriminate between right and wrong. He might kill a person who was worthy to be adored. A self -controlled man does not act against those whose anger has been excited and thereby saves him as well as others, acting as physician in case of both. A wise man, who does not come under the sway of his own anger, even though oppressed, rejoices in

\footnotetext{
${ }^{10}$ RADHAKRISNAN.S, INDIAN PHILOSOPHY,VOL-I , OXFORD, First published in 2005, p.422.

${ }^{11}$ Walli,Koshelya,Ahimsa in Indian Thought, Varanasi,India,Bharata Manisa,first published in 1974,p.15

12 Ibid,pp.18-20.
} 
the next world for having treated a man of anger with indifference. ${ }^{13}$, "In Rāmāyaṇa, Rāma's attitude towards Kaikeyī may be termed as of a type of ahimsa. In the Aranyakāṇ̦a of Rāmāyaṇa,Lakșmaṇa in Pañcavaṇ glorified Bharata and said to Rāma -How can mother Kaikeyī , whose husband is Daśaratha and son Bharata, can have such crooked ways'? Hearing the, non-violent Rāma who believed in returning good for evil and saw good in humanity replied-'my brother, you should by no means, tax our second mother. The above word can note the belief of Rāma in the creed of 'forgive and forget'. This is the foundation of Ahimsa." 14

The concept of Ahimsa has been discussed elaborately by the important social, political, and literary figures of India. Their ideals and thoughts of ahimsa influenced the Indians to attain harmony by establishing solidarity with all people. Their principles of forgiveness and harmony not only influenced their own people but also influenced the world to achieve a unity with all men of all places. Among the great figures who discussed elaborately of Ahimsa were Mahatma Gandhi, Rabindranath Tagore, Sri Chaitanya, Ramakrishna, Swami Vivekananda, and others. To understand the Indian views of Peace and harmony it becomes essential to discuss the views and philosophy of these great men.

In modern India Mahatma Gandhi is an example who dedicated his entire life for the cause of truth and non-violence. In fact, he was more a philosopher than politician. All the political strategies that he undertook were based on the principles of ahimsa and truth. His most important political movement was Satyagraha launcher in 1919 at the time when the whole country was fuming in an anti-British fire. It was a non-violent mass movement to give the impetus to the common mass to fight against the British for their rights. The term Satyagraha is derived from two Sanskrit terms 'satya' meaning truth and 'agraha' or adherence. Thus, the etymological meaning of the term goes as adherence to truth or truth force. Truth force is also known as soul force.Gandhiji views that anyone of any community who seeks redress of wrong can practise Satyagraha for success. The community's purpose in that case must accord to the truth; its methods must accord to truth. By adopting Satyagraha the individual or community, not only obtain immediate purpose but also achieve their spiritual regeneration. The triumph achieved would be for the one and his opponent alike, for it would induce in the opponent its own appreciation of truth. In the political action, Gandhiji divided Satyagraha in two main branches -The Civil Disobedience and Non-Cooperation movement. They are however overlapping with each other only differencing in the degrees of enforcement. Civil Disobedience entailed in breaking unjust laws and courting arrests that the civil disobedient would try until there is a change of heart of the opponent. Even in imprisonment the civil disobedient is happy and try to change the jail environment through love. However, inside the jail, he could not fight against the oppressors directly, but he will try to resist non- violently to any kind of unjust things e.g not accepting food if given improperly or with disrespect.

Non-Cooperation on the other hand is a dynamic based on the power of the people themselves and not based on appeals. Non-cooperation is refusing to cooperate with the opponent and refusing to submit to the injustice. It includes in its programme agendas like non-payment of taxes, strikes, withdrawal of students from English schools, economic boycotts like boycotting foreign goods, refusing to attend government functions and the like. Non-cooperation too was to be carried out in a civil manner. In non -cooperation the non-co-operator may face beatings, imprisonment, or confiscation of their property. It was hoped that the sufferings of the non co-operator would sometime bring change in the heart of the oppressor. Actually, Gandhiji believed that the original power of the tyrant lied in the obedience of the people and not on prisons or guns. If the people stop obeying the tyrant then the tyrant would loss all his powers. No government to Gandhi could work without the cooperation of the people. If the people become disobedient, the government crumbles to dust.

\section{In practising Satyagraha Gandhiji laid down certain rules to be followed by a Satyagrahi}

1) A Satyagrahi will harbour no anger.

2) He will suffer the anger of the opponent.

3) In doing so he will put up with assaults from the opponent, never retaliate; but he will not submit, out of fear of punishment or the like, to any order given to anger.

4)When any person in authority seeks to arrest a civil resister has any property in his possession as a trustee, he will not resist the attachment or removal of his own property ,if any, when it is sought to be confiscated by the authorities.

5) Non-retaliation excludes swearing and cursing.

6)A Civil resister will never insult his opponent, and therefore also not take part in many newly coined cries which are contrary to the spirit of Ahimsa. ${ }^{15}$

Gandhiji's ahimsa had a great similarity with the Jaina concept of ahimsa. Like the Jaina Gandhi considers ahimsa in a very rigorous sense. He takes ahimsa in the normative sense as a dharma the avoidance or non-

\footnotetext{
13 Ibid,pp.48-49.

${ }^{14}$ Ibid,pp.49-50.

${ }^{15}$ Gandhi,M.K,The Selected Works of Mahatma Gandhi,Thevoice of truth,vol-iv,Amedabad,Navajivan,p.188.
} 
performance of which leads to sin. In the Satyagraha movement, Gandhiji transformed ahimsa from a principle of individual behaviour to one of group behaviour thus changing its traditional value.

\section{Gandhiji's concept of ahimsa covers some important aspects. They are- Truth is the end, Ahimsa is the means}

Truth to Gandhi is the highest aim of life. Truth to Gandhi is the end and ahimsa is the means to attain truth. Gandhi views that if one takes care of the means he is bound to reach the end. Hence, if anyone undertakes the path of ahimsa he will reach the end i.e. the truth. To Gandhi both truth and ahimsa are inseparable as they are both the two sides of the same coin.

\section{Truth was positive,non-violence negative}

Gandhiji views that truth stands for the fact while non-violence negatives the fact. Gandhiji holds that the acceptance of truth leads to the acceptance of non-violence.

\section{Ahimsa to Gandhi is the virtue of the strong}

Gandhi considers ahimsa as the virtue of the strong. The true courage and practicality of ahimsa lies in challenging himsa. Gandhiji has no sympathies for those who try to avoid problems, war, or miscreants and claim them as non-violent. Gandhi pieties them who adopt the peaceful path out of fear. Ahimsa can never be possessed by the weak. A mouse cannot be non-violent to a cat as it lacks the basic requirement of courage in it. Ahimsa finds its true meaning in behaving non-violently at the face of brute force. Its true courage lies in compelling the sword bearer to renounce brutality by the force of love.

\section{Gandhiji's ahimsa is a active process and not passive}

Ahimsa thus is not the passivity of the weak. It is essentially active. Gandhiji says, "I seek entirely to blunt the edge of the tyrant's sword, not by putting up against it a sharper weapon but by disappointing his expectations that I would be offering his physical resistance. The resistance of the soul that one offers instead would elude the opposer. It would at first dazzle him and at last compel recognition would uplift him ultimately humiliating him." 16

\section{The courage of ahimsa is different from the courage of himsa}

The courage of non-violence is different from the courage of the violence. These two courages differ in their practicability and standpoint. The qualities like truthfulness, love, self- sacrifice are the courage of ahimsa. They have much higher value than the courage of violence.

\section{Non -violence is applicable to the whole society}

To Gandhi non-violence is meant not only for individuals to attain salvation but it was the rule of conduct for the whole society. The society to march forward in dignity and peace must follow the path of non violence. Then only it can achieve the long cherished peace and harmony.

\section{Non -violence is practicable by all}

Non -violence is practicable by all-children, women, old everyone. The path of non-violence can be only attained when one develops an equal unconditional love for everyone. It is through non -violence the society can prosper to its fullest.

Another important figure of India is Rabindranath Tagore. He was a humanist per excellence who dedicated his entire life for the cause of humanity. In his literary works, social and religious concepts and political views he held man in higher esteem. Tagore has taught humankind how to attain salvation through love. Time again through his creations he taught the world that true renunciation lies not in asceticism or selfdenial but in building up a connection of love with all men. His philosophy revolves round the central thesis of loving man and to realise oneself in harmony with the universal man. This universal man is the humanness, which flows in the blood of every human being. Tagore calls this realizing the individual self in harmony with the universal self. A great admirer of Upanishads especially Katha, Kena, and Isaponisad the entire philosophy of Tagore is soaked with the idea of the Brahman from which all things emerge and in which everything dissolves. Thus, Tagore says realizing the true nature of Brahman one realizes oneself. Moreover, this realization gets its shape when we treat all living beings as part of the eternal Brahman. In addition, this realization includes loving all beings as one's own. Tagore was also greatly influenced by the Buddhist's concept of Ahimsa. The Buddhist's concepts of sublime moods of metta, karuna, mudita, uppekkha touched his heart. He was influenced the Buddhist conception of Karuna or compassion for all living beings. Tagore thus

\footnotetext{
${ }^{16}$ Ibid,pp. 179-180.
} 
believed that one's freedom lies in realising the harmony of one's self with the universe. Time again he has expressed this fact in his philosophical writings like Creative Unity, Sadhana, Religion of Man and other essays. He said that if we forget this greatest truth then soon or other we will court our own disaster. However, modern material centric civilizations have perhaps forgotten this truth. They try to count humanity in terms of the material and economic output. Hence, disaster is inevitable. Tagore has explained this empathetically in the essay Creative Unity. To quote Tagore:

"It has been said in the Upanishads:

Yastu sarvāni bhutāni ātmānyevānupashyati

Sarva bhuteshu chātmānam na tato vijugupsate

(He, who sees all things in âtmā, in the infinite spirit, and the infinite spirit in all beings, remains no longer unrevealed.)

In the modern civilization, for which an enormous number of men are used as materials, and human relationships have in a large measure becomes utilitarian, man is imperfectly revealed. For man's revelation does not lie in the fact that he is a power, but that he is a spirit. The prevalence of the theory, which realizes the power of the machine in the universe and organizes men into machines, is like the eruption of Etna, tremendous in its force, in its outburst of fire and fume; but its creeping lava covers up human shelters made by the ages, and its ashes smother life."17

Thus, Tagore was a preacher of Universal Humanism. He preaches us of cooperation with all people. To him it is a fact though all of us have our own distinct individualities, which are unique in one. This difference has to be accepted and humanity cannot be pressed under the iron of sameness. However, we can overcome our differentness and live in cooperation and harmony with all. We should remember that in spite of our apparent uniqueness we are but the parts of the eternal whole, which comprises our beings. The philosophy of India always believed in the eternal principle of Unity in diversity. Tagore reminded us this philosophy and asserted that our Indian history is the history of assimilation of various races. In India, there came the Huns, Sakhs, Pathans, Moguls and all of them were mingled in the eternal flow of the greater entity named India. India has accommodated all races who came here in her fold. In the west, their history developed in subjugating one race by the other or by complete alienation of one race by the other. Nevertheless, in India there is the philosophy of assimilation, not alienation. Tagore had preached this eternal philosophy.

Another great preacher of humanity was Maha Prabhu Sri Chaitanya. He preached the religion of love, purest love of man, high or low, rich or poor. His religion was open to all and was not separated by any dialectics and metaphysics. He created a religious fraternity with different parts of the world. His religion is called Vaishnavism, which always sought to divinize man. Man and the eternal brotherhood between men is the centre of his religious beliefs.

The Bauls of Bengal and medieval saints of India like Nanak, Kabir were also great preachers of humanity. The Bauls did not believe in any images, temples, scriptures, or ceremonials. They declare in their songs the divinity of man and express an intense feeling of love for man. They crusaded against any kind of caste or secretarianism neither did they invoke any God of cosmic force. To them God is the man of the Heart (maner manush) a human personality. Thus, Man to them is the supreme consideration.

The discussion becomes incomplete if do not mention the names of two great men-Ramakrishna Paramhansa and Swami Vivekananda. Ramakrishna Paramhansa preached us the gospel of universal religion. He preached that God could not be found in the closed door of temples.But, he is within us -in the hearts of all men, in the lowliest of the low. His disciple Swami Vivekananda continued the legacy of Ramakrishna and preached a common basis of Hinduism among the various fighting Hindu -sects. He was the pioneer who accepted that all Hindu doctrines and all sects as different aspects of one total view of reality and way of life called Hinduism. He preached the common people that there is a common basis of Hinduism though there may be different ideologies. During the time of British-ruled colonial India harmony, accord, unity etc completely vanished from Indian society. Swami Vivekanda inculcated a sense of togetherness among the deprived masses. As a social reformist, Swami Vivekananda established Ramakrishna Mission for the social cause of imparting education to the poor masses and uplifting them. The Mission also run hospitals, schools, and colleges; perform rehabilitation work for victims of natural calamities and various other social works across the world.

Thus, we could find that the Indian thinkers had always preached about peace, universal goodwill, and harmonious living of all beings. They were believers of love between human being and not war. War could not solve the raging problems of human beings. The problems of hunger, occupation, literacy cannot be solved by declaring wars by one nation against the other. However, for centuries war, which is an organized effort to kill one another, has been eulogised as a natural and wholesome commitment of a nations's life.S.Radhakrishnan in his book Religion and Society stated some quotations of eminent men of the west to show how they glorified war. "Nietzsche said: "For nations that are growing weak and contemptible, war may be prescribed as a remedy,

\footnotetext{
17 Tagore Rabindranath, 'Creative Unity’ in Rabindranath Tagore Sellected Essays,New Delhi,Rupa,First Published in 2004,pp61 -62.
} 
if indeed they really want to go on living." He declares: "Man shall be trained for war and woman for the recreation of the warrior; all else is folly."...Ruskin said: "I thought in brief , that all great nations realised their truth and strength of thought in war, that they were nourished by war and wasted by peace, taught by war and deceived by peace; in a word ,they were born in war and expired in peace." ${ }^{\prime 18}$

The Hindu scriptures look upon ahimsa or non- violence as the highest virtue.In the Chadogya Upanisad it is said that even in Yajňas the gifts are moral qualities. In the Puranic ages, we find the ashramas or forest hermitages where a spirit of friendliness prevailed between man and animal. The hindu view does not find the divine in complete detachment from the common life. The concrete demands of each particular situation are studied and principles are adapted to it. However, in Hindu, scriptures and epics like Ramayana and Mahabharata there are references of war but they are only the demands of the situations. They are just wars to destroy the evils. An unwarranted use of force is violence. The Hindu dharma always detests this violence. The Indian thinkers too detest unwarranted violence. They always speak of harmony and love between beings to solve the problems. War to them can never be the first option.Thus, Indian culture, Indian thought have always taught the world the gospel of love, friendship and unity. Thus ,Mahatma Gandhi had very aptly said 'An eye for a eye makes the whole world blind."

\section{Bibliography}

[1]. RADHAKRISNAN.S, INDIAN PHILOSOPHY, VOL-I , OXFORD, First published in 2005, p.422.

[2]. Maita Susil Kumar,The Ethics Of The Hindus,Calcutta,University of Calcutta, first published in 1963,pp.7-8.

[3]. Peter Heehs (Edited).Indian Religion, the Spiritual Traditions of South, Delhi: Permanent Black, First published in 2002, pp.40-41.

[4]. Walli,Koshelya,Ahimsa in Indian Thought, Varanasi,India,Bharata Manisa,first published in 1974,p.15

[5]. Gandhi,M.K,The Selected Works of Mahatma Gandhi, The voice of truth,vol-iv,Amedabad,Navajivan,p.188.

[6]. Tagore Rabindranath, 'Creative Unity' in Rabindranath Tagore Selected Essays, New Delhi, Rupa, First Published in 2004, pp6162.

[7]. S.Radhakrishnan,Religion and Society,London,George Allen And Unwin Ltd, first published in 1947,p-199.

[8]. Singh .N.K and Mishra.A.P. (Edited), Encyclopaedia of Oriental Philosophy and Religion, Vol-8, New Delhi: Global vision Publishing House, First published in 2007, p.126-127.

[9]. Radhakrishnan.S and Moore.A.Charles (Edited).A Source Book of Indian Philosophy,New Jersey: Princeton University Press, First published in 1957, p.227-228.

[10]. Swami Lokesarananda, Isapanisad, Upanisad,Kolkata:Ananda publishers, first published in 1999,p.4

[11]. Radhakrishnan.S (Edited).The Principal Upanisads, New York: George Allen \& Unwin Ltd, first published in 1953.

${ }^{18}$ S.Radhakrishnan,Religion and Society,London,George Allen And Unwin Ltd,first published in 1947,p-199. 